\title{
PROFIL PEMBELAJARAN UNGGAH-UNGGUH BAHASA JAWA DI SEKOLAH DASAR
}

\author{
Muh. Arafik \\ Rumidjan \\ Jurusan KSDP Prodi PGSD FIP Universitas Negeri Malang \\ Jl. Semarang No. 5 Malang \\ Email: arafikmuh@gmail.com
}

\begin{abstract}
Javanese language at elementary school. the variety of activities that is done by the teacher's and the students during the process of teaching politeness in javanese language subject at SDN Penanggungan Malang. The approach that was used in this research is qualitative methodology. The data was collected during the process of teaching javanese langage subject at SDN Penanggungan Malang which is done through the problem case study used qualitative analysis. Therfore, this research will result in the construction models of the practice teaching politeness in javanese language at elementary school. Model immersion learning is model of teaching which has attempt to directly involve the students in the learning process.
\end{abstract}

Keywords: teaching, politeness, and javanese language.

\begin{abstract}
Abstrak: Tujuan penelitian ini untuk mendeskripsikan model Pembelajaran Unggah-Ungguh Bahasa Jawa di Sekolah Dasar. Aktifitas apasaja yang dilakukan oleh siswa dan guru dalam pembelajaran unggah-ungguh Bahasa Jawa di SDN Penanggungan Kota Malang. Pendekatan yang digunakan dalam penelitian ini adalah pendekatan kualitatif. Data diperoleh melalui praktik Pembelajaran Bahasa Jawa di SDN Penanggungan Kota Malang, melalui penelitian studi kasus dengan analisis kualitatif, maka penelitian ini akan menghasilkan konstruksi Model Praktik Pembelajaran Unggah-Ungguh Bahasa Jawa di Sekolah Dasar. Model Immersion Learning adalah model pembelajaran yang berupaya mencelupkan langsung diri siswa ke dalam proses belajar.
\end{abstract}

Kata kunci: profil pembelajaran, unggah-unggguh bahasa Jawa.

Pemberdayaan Pembelajaran Bahasa Jawa perlu dioptimalkan dalam upaya mempertahankan kekayaan budaya bangsa yang tidak ternilai harganya. Pembelajaran Bahasa Jawa pada dasarnya dapat dijadikan wahana penanaman watak, pekerti, teerutama melalui penerapan unggah-ungguh pada masyarakat Jawa serta memiliki peran sentral dalam pengembangan watak, dan pekerti bangsa. Sejalan dengan hal ini, model pendidikan karakter yang baik, mencakup sisi-sisi misalnya: dari sisi perencanaan, kualitas proses pembelajaran, dukungan situasi dan kondisi lingkungan belajar, peran serta masyarakat. Model pendidikan karakter terdiri atas modelmodel: pengembangan pendidikan karakter melalui: proses pembelajaran di kelas, pengembangan kultur kehidupan sekolah, kegiatan ekstrakurikuler, dan peran serta masyarakat (Sa'dun, 2014).

Pembelajaran Bahasa Jawa diharapkan dapat membantu peserta didik mengenal dirinya, lingkungannya, menerapkan dalam tata krama 
budayanya, menghargai potensi bangsanya, sehingga mampu mengemukakan gagasan dan perasaan, berpartisipasi dalam masyarakat, dan dapat menemukan serta menggunakan kemampuan analisis, imajinatif dalam dirinya.

Kolar, dkk (2010) mengungkapkan bahwa kebudayaan lokal perlu dilestarikan untuk membuat sistim kebudayaan berjalan sebagaimana mestinya. Sejalan dengan hal tersebut, (Omen, dkk) mengungkapkan bahwa kemampuan untuk melestarikan kebudayaan lokal tercermin dari kemampuan dalam meningkatkan kemampuan seorang peserta didik. Ardissono, dkk (2012:74) memberikan dasar bahwa pelestarian kebudayaan lokal menjadi dominan seiring dengna laju dan arus perkembangan zaman.

Namun apa yang terjadi di lapangan memperlihatkan bahwa, keberadaan Pembelajaran Bahasa Jawa, berdasarkan hasil observasi belum mencapai hasil yang memuaskan. Pelaksanaan pembelajaran Bahasa Jawa masih banyak menemui permasalahan. Pembelajaran masih menitikberatkan peran guru, sehingga guru mendominasi pelaksanaan PBM. Siswa sangat pasif, tidak semangat, tidak tertarik, dan mengaggap bahasa Jawa itu sulit. Siswa lebih menitikberatkan pada materi kognitif, kurang pada aspek psikomotor dan afektif. Siswa belum mempraktikkan.

Bahasa Jawa di Sekolah, keluarga, dan masyarakat. Pemahaman siswa terhadap kosa kata Bahasa Jawa sangat minim. Pengetahuan dan penerapan unggah-ungguh sangat sulit dan kaku. Banyak guru yang kurang memahami dan menguasai materi, karena tidak didukung oleh latar pendidikan bahasa Jawa.Teladan dari guru untuk ditiru siswa masih kurang. Fasilitas media maupun alat peraga yang digunakan masih sedikit/kurang. Kurangnya perhatian beberapa pihak yang menganggap Bahasa Jawa adalah mata pelajaran yang tidak penting. Pembelajaran belum memberi kontribusi berarti dalam perubahan pola tingkah laku negatif menjadi positif. Pembelajaran Bahasa Jawa belum dikemas dalam skenario yang mencerminkan penanaman pendidikan watak dan pekerti bangsa.

Selain itu, untuk aspek kebahasaan lebih menekankan pada bentuk, nilai, dan fungsi kesantunan berbahasa. Bentuk kesantunan berbahasa dapat dilihat dari bentuk lokusi tindak tuturnya, bermodus interogatif atau kalimat pertanyaan, atau bermodus imperatif atau kalimat perintah. Nilai kesantunan berbahasa dapat dilihat dari ilokusi dan isi tuturan yang mematuhi prinsipprinsip kesantunan berbahasa Jawa dan ketepatan penggunaan unggah-ungguh basa. Fungsi kesantunan berbahasa dapat dilihat dari perlokusi atau efek yang ditimbulkan dari perlokusi atau efek yang ditimbulkan dari penggunaan tindak tutur tersebut (Nurhasarah, dkk, 2014; Rahadini \& Suwarna 2014).

Suharti (2006:151), Pembelajaran Bahasa Jawa selain mengajarkan bahasa dan sastra Jawa juga perlu diarahkan untuk terjadinya transfer nilai-nilai budaya didalamnya. Senada dengan Suharti, Wibawa (2006:68), menambahkan bahwa proses Pembelajaran Bahasa Jawa hendaknya dapat dilaksanakan tidak sekedar meaning getting, tetapi berupa proses meaning making, sehingga akan terjadi internalisasi nilai-nilai dalam diri siswa. Dengan pola itu, siswa tidak saja dijejali dengan seperangkat kaidah untuk dimengerti secara kognitif, tetapi diarahkan untuk pengembangan aspek afektif, sesuai dengan sifat Bahasa Jawa itu sendiri yang penuh akan makna muatan afektif. Pendidikan afektif seperti aspek: emosi, nilai, kepercayaan, dan sikap.

Selain itu bagi sebagian siswa, pelajaran aksara Jawa merupakan pelajaran yang cukup rumit, karena terdapat bentuk aksara, hafalan, pelafalan, dan penyusunan aksara yang cukup sulit. Maka untuk meningkatkan minat siswa dalam mempelajari aksara Jawa, metode seperti media pembelajaran berbasis multimedia sangat membantu dalam proses pembelajaran. Perkembangan teknologi multimedia dapat merubah cara belajar seseorang pada umumnya menjadi cara belajar yang lebih interaktif dan memberikan hasil yang lebih baik (Hakim \& Purnama, 2012; Kartikasari \& Nugroho, 2010).

Mengingat kemampuan yang diketahui dari nilai pembelajaran Bahasa Jawa di SD cenderung rendah, pertanyaan yang segera muncul adalah bagaimanakah kondisi pembelajaran Bahasa Jawa di Sekolah Dasar. Aktivitas apa saja yang dilakukan guru dalam pembelajaran tersebut? Aktivitas apa saja yang dilakukan agar siswanya memahami dan trampil dalam menguasi materi unggah-ungguh basa? Pertanyaan-pertanyaan itulah yang akan dicari jawabannya melalui penelitian ini. Melalui penelitian ini diharapkan akan terungkap profil pembelajaran Bahasa Jawa di Sekolah Dasar. 


\section{METODE}

Pendekatan yang digunakan dalam penelitian ini adalah pendekatan kualitatif. Pendekatan kualitatif dalam penelitian ini dimaksudkan agar dapat mengetahui serta mendeskripsikan secara jelas dan terperinci apa adanya tentang pembelajaran Bahasa Jawa di SDN Penanggungan Kota Malang. Penelitian ini juga tergolong studi kasus karena penelitian ini hanya mendeskripsikan proses pembelajaran $\mathrm{Ba}-$ hasa Jawa pada subjek tertentu yang sangat mungkin hasilnya tidak dapat digeneralisasikan. Kehadiran peneliti di lokasi dalam penelitian ini adalah sebagai pengamat penuh, artinya peneliti mengamati secara penuh tanpa terlibat langsung dalam proses pembelajaran. Peneliti mengadakan interaksi dengan subjek penelitian atau objek penelitian.

Data penelitian ini adalah aktivitas guru dan siswa dalam pembelajaran Bahasa Jawa. Aktivitas yang dianalisis meliputi pendahuluan pembelajaran, aktivitas inti, dan aktivitas penutup. Sumber data penelitian ini adalah rekaman video pembelajaran Bahasa Jawa dengan materi unggah-ungguh bahasa Jawa. Rekaman video tersebut merupakan rekaman aktivitas pembelajaran yang dilakukan guru secara alami (real teaching). Rekaman tersebut merupakan kondisi alami maksimal yang dilakukan guru dalam pembelajaran Bahasa Jawa. Dikatakan kondisi maksimal karena sebelum direkam guru sudah diberi tahu untuk mempersiapkan diri secara maksimal. Dalam pembelajaran tersebut tidak ada skenario dari pihak lain selain betul-betul alami kreasi guru.

Data dianalisis secara kualitatif dengan langkah identifikasi, klasifikasi, dan generalisasi. Untuk memperoleh kesahihan hasil, triangulasi dilakukan dengan memperlama masa pengamatan dan memperbanyak pengamat. Upaya memperlama masa pengamatan dilakukan dengan cara mengamati rekaman secara berulang-ulang sehingga hasilnya memadai. Upaya memperbanyak pengamat dilakukan dengan cara menambah jumlah pengamat menjadi tiga orang. Data dikumpulkan melalui teknik wawancara, observasi partisipatif, dan dokumentasi. Wawancara digunakan untuk mengumpulkan data tentang apa sajakah persiapan guru sebelum melaksanakan pembelajaran di kelas. Wawancara juga digunakan untuk mengumpulkan data tentang bagaimana proses atau diimplementasikan Pembelajaran Bahasa Jawa di kelas. Wawancara juga digunakan untuk mengungkap apa sajakah kegiatan pascapembelajaran.

\section{HASIL DAN PEMBAHASAN}

Hasil observasi keterampilan guru dalam mengelola pembelajaran bahasa Jawa diperoleh data sebagai berikut. Kemampuan Melakukan Prapembelajaran (keterampilan membuka pelajaran). Pada indikator keterampilan guru dalam melakukan prapembelajaran, dengan kategori baik. Hal ini ditunjukkan dengan adanya 3 deskriptor yang tampak yaitu: 1) mempersiapkan sumber belajar, 2) kegiatan yang dilakukan guru adalah mempersiapkan Laptop, LCD, Lembar Kerja, dan lembar evaluasi, 3) mengkondisikan siswa.

Guru menyuruh siswa duduk sesuai dengan tempatnya masing-masing. Pengaturan tempat duduk disesuaikan dengan kondisti fisik dan kognitif siswa agar semua siswa bisa menerima pelajaran dengan baik. Guru juga memberikan nasihat kepada siswa agar siswa bersikap tenang sebelum pelajaran dimulai. Guru mengecek kehadiran dengan memberikan pertanyaan kepada siswa, "Sinten ingkang mboten mlebet/absen?".

Guru Melakukan Apersepsi (keterampilan membuka pelajaran) Ada 2 deskriptor yang muncul pada indikator keterampilan guru dalam melakukan apersepsi. Deskriptor tersebut adalah: 1) memberikan apersepsi yang berkaitan dengan materi yang akan diajarkan. Guru memberikan pertanyaan yang menggiring siswa berpikir menuju tema yang akan dibahas, 2) apersepsi sesuai dengan hal-hal yang konkrit. Apersepsi diberikan melalui pertanyaanpertanyaan yang berkaitan dengan hal-hal yang dilakukan siswa sehari-hari. Dari skor yang diperoleh, dapat disimpulkan guru masih dikatakan cukup dalam melakukan apersepsi.

Menyampaikan Tujuan dan Langkah-langkah Pembelajaran (keterampilan membuka pelajaran). Pada indikator keterampilan guru dalam menyampaikan tujuan dan langkah-langkah pembelajaran, mendapatkan skor 2 dengan kategori cukup, hal ini ditunjukkan dengan adanya dua deskriptor yang tampak yaitu: tujuan sesuai dengan indikator yang telah ditetapkan dan menampilkan tujuan dengan menggunakan Power Point atau ditulis pada white board. Menyajikan materi sebagai pengantar (keterampilan menjelaskan). Pada indikator kete-rampilan guru dalam meyajikan materi sebagai pengantar, mendapatkan skor 3 dengan kategori baik, hal ini ditunjukkan dengan 3 deskriptor yang tampak yaitu: 1) menyajikan materi dengan jelas 
Guru menyajikan materi secara runtut. Materi yang dijelaskan saling terkait satu dengan yang lain. Pada saat menjelaskan materi, guru menggunakan suara yang keras sehingga penjelasannya bisa didengar oleh semua siswa, 2) materi disajikan sesuai dengan tema Materi yang disajikan guru sesuai dengan tema yang telah ditetapkan yaitu tema Kegiatanku. Guru memberikan materi tentang kegiatan anak mulai dari bangun tidur sampai sore hari, posisi matahari, dan apa itu basa krama lugu

Penyajian materi dilakukan dengan menarik. Penyajian materi dilakukan semenarik mungkin dengan menggunakan $P P T$. Penggunaan $P P T$ diharapkan dapat menarik perhatian siswa untuk memperhatikan penjelasan guru. Memperlihatkan Gambar Kepada Siswa (Keterampilan mengadakan variasi pembelajaran) Pada indikator keterampilan guru dalam memperlihatkan gambar kepada siswa mendapatkan skor 3 dengan kategori baik, hal ini ditunjukkan dengan 3 deskriptor yang tampak yaitu: 1) gambar sesuai dengan tema. Guru menyajikan beberapa gambar tentang kegiatan siswa mulai dari bangun tidur samapi sore hari sehingga bisa ditarik kesimpulan bahwa gambar tersebut sesuai dengan tema, 2) gambar disajikan secara acak. Gambar disajikan guru melalui $P P T$ secara acak agar dapat diurutkan oleh siswa, 3) gambar menarik Gambar yang ditampilkan berwarna sehingga siswa tertarik.

Membimbing siswa dalam berdiskusi (keterampilan membimbing kelompok kecil dan mengelola kelas). Deskriptor yang muncul pada indikator keterampilan guru dalam membimbing siswa adalah 2 deskriptor. Dari 2 deskriptor tersebut, maka guru mendapatkan skor 2 dengan kategori cukup. Deskriptor yang tampak yaitu: 1) mengatur tempat duduk siswa sesuai dengan kelompok. Guru mengelompokkan siswa dengan anggota tiap kelompok sebanyak dua siswa. Anggota kelompok merupakan teman sebangku siswa, sehingga guru tidak memperbolehkan siswa pindah ke tempat dudu lain, 2) berkeliling membimbing diskusi. Guru berkeliling di dalam kelas untuk mengamati jalannya diskusi. Selain itu memberikan penjelasan jika ada siswa yang belum paham tentang tugas yang diberikan guru. Terkait hal ini, dalam pembelajaran bahasa Indonesia ada empat profil pembelajaran membaca di sekolah dasar yaitu: (1) menyimak sambil mambaca, dijelaskan isinya, menjawab soal, dan menceritakan isinya, (2) membaca judul, bergantian membacakan teks, mencari isi paragraph, menjawab pertanyaan, dan bergantian membacakan teks, (3) membaca keras bersama-sama, dijelaskan isinya, permainan kata, mencari pokok pikiran, mengerjakan latihan, dan mengarang berdasarkan gambar, dan (4) membaca dalam hati, berlatih bercerita, bercerita di depan kelas, dan menuliskan kembali isi cerita (Basuki, 2011).

Memberikan kesempatan kepada siswa untuk mengurutkan gambar (keterampilan mengadakan variasi pembelajaran). Pada indikator keterampilan guru dalam memberikan kesempatan pada siswa untuk mengurutkan gambar, terdapat 3 deskriptor yang tampak. Ketiga deskriptor tersebut adalah: 1) memanggil siswa secara acak untuk mengurutkan gambar. Guru memberikan kesempatan kepada setiap siswa untuk mengurutkan gambar dengan cara menunjuk siswa secara bergilir. Dengan menunjuk secara bergiliran, semua siswa akan mendapatkan kesempatan, 2) memberikan pengarahan kepada siswa ketika mengurutkan gambar. Guru memberikan pengarahan kepada siswa agar bisa mengurutkan gambar dengan benar, 3) memberikan pertanyaan tentang isi gambar yang telah diurutkan.

Guru memberikan pertanyaan tentang isi gambaryang telah diurutkan agar siswa mudah dalam memceritakan gambar. Kemampuan Menjelaskan Urutan Gambar (keterampilan memberikan penjelasan) Pada indikator keterampilan guru dalam menjelaskan urutan gambar mendapatkan skor 2 dengan kategori cukup, hal ini ditunjukkan dengan adanya 2 deskriptor yang tampak yaitu: menjelaskan isi masing-masing gambar dan mengurutkan gambar dengan benar. Memberikan Penguatan Kepada Siswa (keterampilan memberikan penguatan). Pada indikator keterampilan guru dalam memberikan penguatan mendapatkan skor 2 dengan kategori cukup, hal ini ditunjukkan dengan adanya 2 deskriptor yang tampak yaitu: 1) memberikan penguatan verbal. Guru memberikan ucapan bagus, pintar kepada siswa yang aktif dalam pembelajaran, 2) memberikan penguatan berupa hadiah. Guru memberikan stiker kepada siswa yang berani berbicara krama lugu di depan kelas.

Terkait dengan pemilihan model pembelajaran yang akan dipergunakan untuk mata pelajaran Bahasa, Sastra, dan Budaya Jawa, selain harus memperhatikan kelima faktor-faktor tersebut di atas tentunya yanng tidak kalah penting harus memperhatikan karakteristik pelajaran Bahasa, Sastra, dan Budaya Jawa itu sendiri. Kompetensi yang diamanatkan 
dalam mata pelajaran Bahasa, Sastra, dan Budaya Jawa mempertimbangkan kedudukan dan fungsi bahasa Jawa, Dalam hal ini kedudukan bahasa Jawa sebagai bahasa daerah berkedudukan sebagai; (1) lambang kebanggaan daerah, (2) lambang identitas daerah, dan (3) alat perhubungan di dalam keluarga dan masyarakat saerah. Sedangkan fungsi bahasa Jawa khususnya mata pelajaran Bahasa, Sastra, dan Budaya Jawa adalah sebagai; (1) sarana pembina rasa bangga terhadap bahasa Jawa, (2) sarana peningkatan pengetahuan dan keterampilan dalam rangka pelestarian dan pengembangan budaya Jawa, (3) sarana peningkatan pengetahuan dan keterampilan untuk meraih dan mengembangkan ilmu pengetahuan, teknologi, dan seni, (4) sarana penyebarluasan pemakaian bahasa Jawa yang baik dan benar untuk berbagai keperluan menyangkut berbagai masalah, dan (5) sarana pemahaman budaya Jawa melalui kesusasteraan Jawa. Terkait dengan itu ditetapkanlah standar kompetensi mata pelajaran Bahasa, Sastra, dan Budaya Jawa yang mencakup kemampuan berbahasa dan bersastra dalam kerangka budaya Jawa. Aspek-aspek tersebut perlu mendapat porsi yang seimbang dan dilaksanakan secara terpadu. Di samping itu, kompetensi berbahasa dan bersastra dalam kerangka budaya Jawa meliputi aspek menyimak, berbicara, membaca, dan menulis, keempat aspek kompetensi tersebut dalam pelaksanaannya harus secara terpadu.

Penerapan keterpaduan dari berbagai aspek tersebut nampak sebagai misal seorang guru akan menyampaikan kompetensi memahami dan menanggapi sesorah dalam berbagai kegiatan di masyarakat. Jika dilihat dari aspek keterampilan berbahasa yang terkandung dalam kompetensi itu, maka kompetensi tersebut menekankan pada aspek menyimak, namun dalam menanggapi sesorah itu dapat digunakan keterampilan berbahasa yang lain, dalam hal ini tanggapan dapat dilaksanakan secara lisan maupun tertulis. Sehingga keterapilan menyimak itu paling tidak sudah terpadu dengan keterampilan berbnicara dan menulis. Demikian juga jika dilihat dari isinya, sewaktu menanggapi sesorah tersebut yang dibahas semua aspek yang terkandnung dalam sesorah tersebut, baik dari aspek bahasa, sastra, maupun budayanya.

Penyampaian kompetrensi yang telah diamanatkan oleh mata pelajaran Bahasa, Sastra, dan Budaya Jawa apabila dikaitkan dengan model pembelajarannya secara garis besar dapat dikelompokkan menjadi dua, yaitu model pengorganiasasian pertemuan dan model diskusi kelompok. Merujuk pada model pertemuan yang telah dikembangakan oleh Center for Advencement of Teaching Macquirie University dalam proses pembelajaran Bahasa, Sastra, dan Budaya Jawa dapat menggunakan model antara lain: sajian visual, kerja kelompok, penyajian situasi, penyajian skill. Sedang model diskusi kelompok antara lain dapat menggunakan model kelompok curah pendapat atau brainstorming group, model studi kasus atau case study, model bermain peran atau role play, atapun model simulasi atau simulation.

Unggah ungguh basa adalah sebuah tatanan yang berfungsi untuk mengatur bagaimana seseorang berkomunikasi secara santun atau beradab dengan orang lain. Santun atau beradab maksudnya adalah pantas atau sesuai dengan kondisi penutur, situasi tutur, tujuan bertutur, dan pesan yang dituturkan. Tatanan tersebut lazim disebut dengan istilah komponen tutur atau konteks tutur. Masyarakat tutur Jawa menyebut hal tersebut micara manis atau manut empan-papan lan wektu kelakone. Unggah-ungguh basa dapat dikatan juga sebagai sebuah peraturan berkomunikasi agar komunikasi bejalan lancar tanpa menimbulkan perasaan tidak senang akibat salah paham dalam hal perilaku berkomunikasi maupun salah paham terhadap isi yang dikomunikasikan. Dalam teks wulang Jawa ada beberapa hal yang perlu dipegang teguh oleh seorang penutur agar dirinya selamat dalam bertutur. Hal-hal tersebut antara lain: tingkah sing patut "gerak-gerik yang pantas, setiti ngatiati "teliti berhati-hati", tan kena kanthi sembrana "jangan dengan tidak serius", awya gawe serik "jangan membuat sakit hatie", den sabar awya brangasan "bersabarlah jangan kasar", ngajenana mring sesami "menghormati sesama manusia", dan micara sarwa manis "erbicara serba manis"e (Endraswara, 2006:37).

Kesopanan bertutur dengan bahasa Jawa disamping diatur oleh sikap-sikap seperti yang diuraiakan di atas, masih diatur lagi oleh tingkat tutur atau undha-usuking basa. Tingkat tutur atau undhausuk adalah tingkatan pemakaian bahasa Jawa oleh penutur Jawa yang digunakan dalam berkomunikasi dengan tujuan untuk menghargai dan menghormat mitra tutur. Oleh karena itu, masyarakat Jawa di dalam berkomunikasi selalu mempertimbangkan dengan baik pemilihan jenis tingkat tutur mana yang tepat untuk digunakan. Ketepatan pemilihan tingkat 
tutur akan memperlancar proses berkomunikasi, sebaliknya jika terjadi kesalahan pemilihan tingkat tutur akan terganggulah proses berkomunikasinya, bahkan lebih jauh lagi dapat menimbulkan hal-hal yang kurang menyenangkan diantara keduanya.

Tingkat tutur bahasa Jawa di era ini dipandang memperumit proses berkomunikasi, dan pandangan ini sudah menjadi polemik umum. Hal ini membawa dampak banyak orang yang takut berbahasa Jawa karena merasa kurang menguasai tingkat tutur. Pandangan ini tidak hanya terjadi di kalangan orang dewasa tetapi juga merambah pada anak usia sekolah, sehingga anak usia sekolah merasa berat untuk belajar bahasa Jawa. Apabila ditelusuri secara bijaksana benarkah bahasa Jawa itu sulit? Jawabannya tidak bisa secara serta merta diberikan. Perlu dicari titik kelemahan yang menyebabkan permasalahan tersebut. Berdasarkan analisis fakta letak penyebab sulitnya berbahasa Jawa terletak pada kekurangpahaman masyarakat atau siswa terhadap pengetahuan undha-usuk dan pengetrapannya, serta sikap-sikap berkomunikasi seperti yang telah diuraikan di atas. Agar para guru semakin paham akan permasalah tersebut maka berikut ini akan diuraikan tentang undha-usuking basa Jawa.

Tingkat tutur bahasa Jawa semula/masa lalu muncul dalam varian yang cukup banyak. Tingkat tutur di masa lampau mencakup beberapa tingkatan seperti: tingkat ngoko dengan variasinya, madya dengan variasinya, dan krama dengan variasinya, jika untuk kepentingan berkomunikasi secara umum. Walaupun demikian, penelitian Irtadji menemukan hal yang mengejutkan, yaitu ada seorang guru kelas satu SD yang menggunakan teknik-teknik pembelajaran sederhana mampu memicu penumbuhkembangan kreativitas siswa pada berbagai bidang studi (Irtadji, 2014). Adapun seperti pertuturan diantara para abdi dalem di dalam lingkungan kerajaan diperlukan tingkat tutur khas yang disebut tingkat tutur bagongan untuk kraton Yogyakarta dan tingkat tutur kedhaton untuk kraton Surakarta. Disamping tingkat tutur tersebut masih ada lagi jenis tingkat tutur yang khas digunakan di dalam seni lakon misalnya kethoprak, dan wayang yang tercermin dalam tuturan para Dewa. Tingkat tutur tersebut dinamai tingkat tutur kadewatan atau tingkat tutur khas para Dewa (Nurhayati, 2005: 312-317), merinci tingkat tutur bahasa Jawa menjadi ngoko lugu, ngoko andhap, madya, krama, basa kasar, dan basa kêdhaton. Tingkat tutur ngoko andhap dirinci lagi menjadi antyabasa dan basa antya. Tingkat tutur madya dirinci menjadi madya ngoko, madyantara, madya krama, krama ndésa, krama inggil. Tingkat tutur krama dirinci menjadi wrêdhakrama, mudhakrama, kramantara.

Dalam hal ini, untuk memahami makna tuturan, diperlukan pemahaman terhadap konteks-konteks yang mewadahinya (Mudiono, 2012)

\section{SIMPULAN DAN SARAN}

\section{Simpulan}

Pelajaran bahasa Jawa di sekolah sebaiknya berorientasi pada segi pengalaman siswa sendiri. Siswa harus lebur dan menyatu dengan materi yang diajarkan guru. Siswa harus menjadi subjek pembelajaran, sementara guru menjadi pengarah dan panutan yang bijaksana dan penuh kasih sayang. Untuk mendukung kondisi ideal itu, sarana dan prasarana pembelajaran bahasa Jawa mutlak diperlukan. Sudah saatnya materi hapalan yang kurang terintegrasi dengan kehidupan siswa sudah harus ditinggalkan. Sebab yang lebih penting ialah bagaimana memahami pemakaiannya dalam komunikasi seharihari. Paramasastra, aksara Jawa atau materi hafalan peristilahan lainnya hanyalah salah satu materi pelajaran bahasa Jawa bukan tujuan pengajaran bahasa Jawa, tetapi hanya sebagai sarana mencapai tujuan pembelajaran bahasa Jawa. Apabila bahasa Jawa di sekolah mampu menjadi mata pelajaran yang paling disenangi siswa, atau sekurang-kurangnya tidak dibenci siswa, maka perkembangan kehidupan bahasa Jawa paling tidak secara edukatif akan berjalan dengan baik dan menggembirakan. Mengacu pada paparan data dan analisis hasil penelitian di atas, dapat disarankan bahwa Pembelajaran UnggahUngguh Bahasa Jawa di SDN Penanggungan menggunakan model Immersion Learning. Model Immersion Learning adalah model pembelajaran yang berupaya mencelupkan langsung diri siswa ke dalam proses belajar. Kunci metode ini bahwa siswa akan mengalami langsung apa yang dipelajari. Yang dihindari dalam model ini adalah terlalu banyak verbalistik, karena yang dipentingkan adalah pembelajaran dan pengalaman. Pencelupan dapat dilakukan dengan menggunakan berbagai media seperti ketoprak, wayang, ludruk, dagelan, dan segala 
bentuk sosiodrama. Pemberdayaan peran siswa, akan mengarahkan dirinya memahami komunikasi yang tepat. Praktik unggah-ungguh dapat diperoleh dari upaya meniru seseorang dalam komunikasi.

\section{Saran}

Temuan model pembelajaran unggahungguh disarankan dan direkomendasikan untuk diimplementasikan dan dikembangkan di Sekolah Dasar yang lain. Peneliti selanjutnya dapat mengembangkan atau meneliti model-medel pembelajaran bahasa jawa yang lain, seperti: pembelajaran membaca dan menulis aksara jawa, pembelajaran sesorah, pembelajaran menulis dan membaca cerkak, dan lain sebaginya.

\section{DAFTAR RUJUKAN}

Akbar. S. 2014 Model Pendidikan Karakter Yang Baik (Studi Lintas Situs Bests Practices) Pendidikan Karakter di SD. Jurnal Sekolah Dasar. 23(2):21-33.

Ardissono, L., Kuflik, T., \& Petrelli, D. (2012). Personalization in Cultural Heritage: The Road Travelled and The One Ahead. User modeling and user-adapted interaction, 22(1-2), 73-99.

Basuki, I. A. 2011 Profil Pembelajaran Membaca Pemahaman di Sekolah Dasar. Jurnal Sekolah Dasar. 20(2).

Endraswara, S. 2006. 2010.30 Metode Pembelajaran Bahasa dan Sastra Jawa. Yogyakarta: Kontul Press.

Hakim,A.O.A.A\& Purnama, B.E. 2012. Perancangan dan Implementasi Sistem Pembelajaran Aksara Jawa untuk SD Berbasis Multimedia di SDN Bumirejo 02. Indonesian Jurnal on Computer Science Speed (IJCSS). 9 (3): 55-61.

Irtadji, Tutut, C., \& Rumidjan. 2012. Model Pelatihan Pembelajaran Kreatif Bagi Guru Sekolah Dasar. Jurnal Sekolah Dasar. 21(2):42-54.
Kartikasari, D \& Nugroho, G.K. 2010. Media Pembelajaran Interaktif Mata Pelajaran Bahasa Jawa Pokok Bahasan Aksara Jawa pada Sekolah Menengah Pertama Negeri 2 Tawangsari Kabupaten Sukoharjo. Journal Speed. 2 (3): 1-6.

Kolar, T., \& Zabkar, V. (2010). A consumer-based model of authenticity: An oxymoron or the foundation of cultural heritage marketing? Tourism Management, 31(5), 652-664.

Mudiono, A. 2012. Tindak Ilokusi Direktif Bahasa Indonesia Dalam Wacana di Sekolah Dasar. Jurnal Sekolah Dasar. 21(1):12-24.

Nurhasanah, Wurianto, A.B., \& Arifin, B. 2014. Pengembangan Media KIJANK (Komik Indonesia, Jawa, dan Aksara Jawa) Pemebelajaran Bahasa Jawa Kelas 5 Sekolah Dasar. Jurnal Pemikiran dan Pengembangan SD. 1 (4): 267-273.

Nurhayati. 2005. Modul Pembelajaran Bahasa Jawa. Malang: Fakultas Sastra Universitas Negeri Malang.

Rahadini, A.A \& Suwarna. 2014. Kesantunan Berbahasa dalam Interaksi Pembelajaran Bahasa Jawa di SMPN 1 Banyumas. Jurnal Lingtera. 1 (2): 136-144.

Suharti. 2006. Penerapan Unggah-Ungguh Berbahasa Jawa di Sekolah: Upaya Pembinaan Perilaku Bangsa yang Tangguh. Makalah Konggres Bahasa Jawa IV Tahun 2006 di Semarang.

Wibawa, S. 2006. Pendekatan Pembelajaran Bahasa Jawa di SMA/SMK/MA. Makalah Konggres Bahasa Jawa IV Tahun 2006 di Semarang. 